\title{
China, Globalisation and Crime: A Potential Victim of Its Own Prospective
}

Success?

We are living in a world of global economies. More accurately, and more worryingly perhaps, we are living in a world of aspiring global economies. There are many countries who have until now been unable to enrich their economies through ordinary industrial growth. In part, this was because they lacked the requisite financial sources to do so; in part it was due to increasing, if unfair, western moratoria on ecologically damaging latent development. The beauty and potential danger of the Internet-driven economy lies in the ability of the emerging economies to create and sustain at least the illusion of industrial and capitalist parity with the developed economies of the west until such time that that parity is actually achieved. The problem with illusions however is that they require creative misdirection. The dangers of such sleights of hand being utilised by emerging economies are potentially grave.

The Organisation for Economic Co-operation and Development (OECD) has maintained that e-commerce lies at the very heart of the future of globalisation ${ }^{1}$. For emerging economies the nature and increased volume and complexity of e-trading increases the centrality for them of e-commerce.

Equally, the OECD also argues that "[d]eveloping new kinds of commercial activities in the electronic environment largely hinges on assuring consumers and businesses that their use of network services is secure, reliable and verifiable." ${ }^{, 2}$ In pursuing the economic importance of e-commerce, however, the OECD had actually neglected to fully consider the concept and importance of security in e-commerce. Qu Yuan, writing over 2000 years ago, argued that "[a]11 the world is drunk and I alone am sober."3 Applied to the security void evidenced by the OECD, his words border on the prophetic. 
Globalisation requires, and will continue to necessitate, an increased connectivity of the world's computer, banking and financial systems. Globalisation has increased the free movement of capital between the world's developed and underdeveloped economies. Globalisation operates in cyberspace which by definition is extraterritorial. ${ }^{4}$ This means that the regulatory practices which purport to exist and operate in the land-locked world, and which should be the sine qua non of the globalised economy, are missing. The Economist notes that "...much of the dynamism in global finance... has been due to fewer regulations on the movement of capital, particularly across borders, and on what can be done with it." ${ }^{, 5}$ It goes on to posit an accurate but potentially dangerous truism that "[f]or the most part, money is now free to flow wherever an opportunity presents itself, and has generally done so, leaving everybody better off than with heavy regulation. ${ }^{\prime 6}$ The OECD maintains, somewhat ironically, that there is "...little enthusiasm for a global system of regulation for e-commerce. In global electronic commerce the realities of the borderless world of cyberspace run headlong into geographically delimited national jurisdictions of sovereign states. International law and global international legal institutions certainly exist, but in the burgeoning global digital economy there are enormous difficulties in obtaining agreement on a global basis."

Principally, the OECD is against the notion of global regulation of e-commerce for fear of creating a perception of discrimination against those countries whose systems may not equate with more developed economies. The price to be paid for basing a rationale of non-co-operation on the digital divide that exists between emerged and emerging economies will be a real and definite criminal infiltration of both. Indeed, the Commission on Crime Prevention and Criminal Justice has noted that "[a]s the 
degree of reliance placed on networks increases, the potential harm from criminal offences also increases."

There are, however, few such reservations on the part of transnational organised crime groups. Strategic alliances already exist between Mexican and Colombian drugs cartels, between Mexican and Chinese human traffickers and between Sicilian and Colombian drugs traffickers. ${ }^{9}$

As Williams notes “...cooperation among these organisations is only a natural activity particularly as they share the common problem of circumventing law enforcement and national regulations." $"$ Ironically, Western and emerging economies do not seem to be of the same mind when attempting to deal with their shared common problem - the infiltration by those organised crime groups.

The organised crime groups' success lies, according to Williams, in “...the diversity of these organisations, their symbiotic relationships with legitimate businesses, their capacity to exploit (rather than disrupt) legitimate trading activity and financial institutions, and the ability to corrupt governments and law enforcement agencies." 11 Crime, like nature, abhors a vacuum. It seems inevitable that within China, organised crime groups will positively rush to fill that void. ${ }^{12}$

A prime example of the systemic nature of transnational organised crime groups' lateral thinking and exploitative powers was witnessed in October 2000 when a Sicilian mafia group, together with twenty other strategically placed individuals, created a digital clone of the Bank of Sicily's online component. Its plan, thwarted at the last moment by an informant, involved the diversion of $\$ 400$ million allocated to 
the Bank by the European Union for regional projects within Sicily ${ }^{13}$. The fact that the group tried and failed is not the issue. That they actually conceived the idea is. It does not take too much imagination to envisage the havoc that might be unleashed were the evident flaws within China's computer infrastructure to be exploited by transnational crime groups in a similar fashion.

As a prelude to an examination of China's role in globalisation, it might be prudent to examine the fate of the Former Soviet Union (FSU), especially that of Russia, given that Russia too was once part of an omnipotent Communist system. Georgy Satarov, president of INDEM (a Russian think-tank) noted ${ }^{14}$ in May 2002 that Russian companies paid $£ 25$ billion in bribes and unofficial charges, an amount equating to $12 \%$ of Russia's GDP. The recipients of the largest bribes are members of the judiciary, the same judiciary responsible for ensuring that the financial and banking regulations are enforced through the courts. The black economy, grown large by dint of the collapse of the FSU, accounts for $35 \%$ of the economic activity in Russia ${ }^{15}$. The Centre for Strategic and International Studies (CSIS) argues ${ }^{16}$ that Russia is already a 'criminal-syndicalist' state, comprising corrupt officials at all levels of government, successful full time professional criminals (the Russian Mafiya), and businessmen who seem to regard Russian law and Western norms of commerce, respectively, not as barriers to be respected but as mere obstacles to circumvent. ${ }^{17}$ The CSIS maintains that "corruption at all levels of government had long been the lubricant that made the Soviet system work. In the Soviet Union, the system was the State itself; in a transforming Russia, it is corruption which allows organised crime to function." "Indeed, as Shelley points out, "[t] he pervasive corruption and penetration of organized $[s i c]$ crime into the political process are inhibiting the development of new laws needed as a foundation for a democratic free market economy.",19 
The Russian Mafiya purportedly runs $40 \%$ of private business, $50 \%$ of banks and $60 \%$ of state-owned companies. ${ }^{20}$ They have already infiltrated the USA through activities such as daisy-chaining ${ }^{21}$ fuel scams and have entered the transnational trade in sex trafficking to such an extent that the trade is now known generically as the Natasha $\operatorname{trade}^{22}$. Russia remains on the Financial Action Task Force's (FATF) list of Non-Cooperative Countries and Territories, despite Putins's valiant attempts to introduce and enforce money laundering legislation. Ironically, the USA maintained in June $2002^{23}$ that Russia was now a fully-fledged market economy, one with which, presumably, it wishes to trade. This position ignores the fact, as noted by the Economist in the same month, that Russia “...is governed by forces that might politely be described as unusual - including highly politicised subsidies for energy, transport and credit, a welter of organised crime, and arbitrary bureaucratic interference." ${ }^{24}$ The reason for the USA's apparently blinkered approach is summed up neatly by the Economist when it supposes that "...the laws of supply and demand certainly matter a lot more than they once did. ${ }^{, 25}$ Not for the first time in the world of commerce in general, and e-commerce in particular, justifiable concern has given way to economic pressure. If the USA, and by definition, the rest of the Western global economies, are willing to trade with Russia whilst simultaneously condoning the rank criminality within Russia, it seems likely that they will also turn a collective blind eye to the rank corruption that exists within China. Therein lies a true recipe for disaster in the process of globalisation. Indeed, China's increased and increasing level of trade with Russia ${ }^{26}$ may lead to China's fragile financial system becoming a conduit for Russian criminal proceeds.

Although China has witnessed momentous changes it has not yet undergone Russia's perestroika or glasnost. However, it is, particularly after its entry into the World 
Trade Organisation (WTO), moving rapidly from a centrally planned to a socialist market economy. The corruption that pervades Russia and has precipitated many of its current problems is present in China also.

Time noted, in February 2002, in connection with China's WTO entry that "China has long played the inert Panda to Asia's tiger economies, but this year the panda grows fangs." ${ }^{27}$ Morgan Stanley's Chief Economist, echoing this sentiment, said, "[w]hen [globalisation] is all over China will be the largest exporter in the world." 28 Roston and Fonda note, however, that "..in written Chinese, the same ideogram is used to express both danger and opportunity."29

China can certainly boast one of the most dynamic emerging economies. The average annual growth rate of China's GDP between 1990 and 1999 was $10.7 \% .{ }^{30}$ For governments and MNEs (multi-national enterprises) outside of China, China's population of over 1, 249.6 billion people ${ }^{31}$ and its strong manufacturing base which accounts for $49.3 \%^{32}$ of its GDP represents a potentially lucrative market.

However, this trading must be carried out in an honest and secure environment. The Centre for Security Policy argues (conservatively perhaps ${ }^{33}$ ) that corruption in China accounts for between four and eight percent of $\mathrm{GDP}^{34}$. Such corruption pervades everyday life in China such that it constitutes normality. Even the symbol of China's modernisation process - the Three Gorges dam - is affected. As Ridding has reported recently, "[c]orruption is a constant threat - to the dam's physical structure as well as its financial underpinnings." 35 The Chinese Academy of Social Sciences noted that "unless the problem of corruption is genuinely tackled as a systemic issue, it could become the main cause of social turmoil." ${ }^{, 36}$ The culture of all-pervading corruption ${ }^{37}$ per se is unlikely to change as rapidly as the needs of the globalising economic system in China demands that it should. As Myers puts it, "[t]he introduction of 
capitalism into the guanxi ${ }^{38}$ dominated society of the People's Republic of China has proven an explosive mixture, spawning economic success on the one hand and an ungovernable society riddled with corruption on the other." 39 It is the apparent preeminence of guanxi that supports and perpetuates the corruption which leaves the future security of the economy in jeopardy. As Yao notes, “...the presence of privilege in China's political system is the fundamental cause of implicit corruption in the short run and of explicit corruption in the long run."40 Johnston argues that "reforms and growth have created new opportunities and much higher incentives for illicit connections between wealth and power." ${ }^{41}$ The Economist noted in February 2002 that the annual capital flight from China between 1991 and 2000 rose from $\$ 10$ billion to more than $\$ 45$ billion $^{42}$.

In May 2002, Wang Xuebing, the Bank of Construction's President, was dismissed from office ${ }^{43}$ and is now under investigation for fraud. Wang had been at the Bank of China's New York branch but had been discredited by an American Treasury investigation $^{44}$. The Chinese government, it is reputed ${ }^{45}$, must have known of his malfeasance. That fraud occurred was worrying. That it was systematically hidden was more worrying still.

In November 2001 Ernst and Young found ${ }^{46}$ that almost half of the loans made by Chinese banks might never be repaid. Given that the four main state banks account for $66 \%$ of lending and $60 \%$ of deposits ${ }^{47}$ and that the official government figure for nonpayment is $25 \%{ }^{48}$ (as opposed to the $50 \%$ estimated by Lardy of the Brookings Institution $^{49}$ ) there is understandable and rising concern over the fact and consequences of such financial mismanagement. 
In February 2002 China's only private bank (with whom Western businesses might prefer to conduct business) was embroiled in a fraud scandal involving a loan for $\$ 43$ million made to one of its own tellers. ${ }^{50}$

China's national audit office found that \$320 million of the Bank of China's funds had been diverted from a number of branches via a number of stratagems including unlawful loans. ${ }^{51}$ In March 2002, the Bank of China revealed the theft by five of its officials of $\$ 500$ million. ${ }^{52}$ As Li Peng ${ }^{53}$ warned in a broader but nevertheless relevant context, "[h]istorical experience has proved that the exercise of power without restraint and supervision inevitably leads to corruption." ${ }^{, 54}$ Applied to the banking situation in China, it resonates. It is somewhat ironic, therefore, that the People's Bank of China participated (as a member of the Bank for International Settlements (BIS)) in the drafting and revision of the 25 core principles for effective banking supervision laid down in the Basel Committee on Banking Supervision (BCBS) in 1997. Indeed, in 1999, Tang Xu of the Bank of China argued that "[a]n effective banking system in keeping with the Basel core principles has taken shape in China." 55

Mr Lui, of the Bank of China, recently admitted, though perhaps it was by then selfevident, that it suffered from a “...lack of integrity, compliance, discipline and transparency..."56 The Bank of China has also accepted that "[f]or a commercial bank in the market economy, the criteria of healthy operation include sound corporate governance on the one hand, adequate capital and ability to control and deal with bad debts timely on the other." ${ }^{, 57}$ The various thefts and diversion of huge amounts of capital and the massive number of unjustified loans show clearly that such laudable criteria do not pertain to the Chinese banking system and this raises, as Business Week put it in February 2002, "troublesome questions about China's ability to 
regulate its financial system, even as that system is being thrown open to the forces of the free markets." $" 58$

The OECD notes that the financial system in China "performs inadequately in carrying out several of its basic functions in the economy.",59 It has "limited scope for transferring funds among financial institutions or regions", 60 and that "[ $\mathrm{t}] \mathrm{he}$ external discipline provided by the financial system has been a major weakness. Years of government mandated lending and weak contract enforcement has created a distorted credit culture in which banks have had limited incentives - and even less ability - to maintain strict lending standards and enforce loan agreements. ${ }^{\prime 61}$ In January 2002 the Director of the Fund Management Division at the Chinese Securities and Regulatory Commission reprimanded fund managers on the Chinese stock market for speculative share-dealing on such a scale that the stock market itself could, in his view, have been destabilised. $^{62}$

Ironically, in 2001, the CSRC had noted that "[t]he complexity of Internet technology greatly increases the difficulty of effectively monitoring on-line information. It is reported that the success rate for investigating and handling the fraud cases are relatively low...It will take some time for the current legislation to be adapted to the new technology., 63

To add to the difficulties posed by China's relatively slow development, the CSRC is also somewhat constricted by the Chinese government. Chang argues that "...the nation's stock watchdog seems to be a captive of the industry it is supposed to regulate - this dog just watches all the problems and barks only when prompted."64 More specifically, the OECD has noted generally that "China's financial regulatory and supervisory authorities face especially great challenges given the adverse incentives inherent in extensive state ownership of financial institutions." ${ }^{.65}$ The 
OECD maintains further that “... supervisory authorities still lack full control over some basic prudential standards, such as the power to impose realistic norms for bank provisioning and loan write-offs" $" 66$. The fact that the CSRC has been given the responsibility but not the requisite power for regulating the stock exchanges, bond markets and securities and investment companies ${ }^{67}$ does not augur well for the soundness or security of a financial system which will eventually go online in response to the increased connectivity required by globalisation. Indeed, as things currently stand, Chang notes that "...the exchanges of Shanghai and Shenzhen are infested, plagued by market manipulation, insider trading, accounting fraud, outright theft, and a dozen other corrupt practices." ${ }^{68}$ The Chinese government may believe that they are establishing, through entities like the CSRC, a market-based regulatory system. The point they are missing, however, is that "...regulation is not simply a collection of laws and regulations in individual areas but a process in its own right." 69 Witherell has noted recently that " $[\mathrm{r}]$ ecent high profile cases of governance failure and corporate misconduct...have shown that corporate governance mechanisms sometimes have not kept up with market developments." ${ }^{70}$ In the USA, Enron overstated its profits by almost $\$ 600$ million. Andersen, the supposedly objective auditors shredded Enron-related documentation when it discovered that the Securities and Exchange Commission (SEC) had launched an investigation into Enron's accounting. WorldCom recorded losses over five quarters (from the beginning of 2001) as profits and Xerox overstated its profits by $\$ 1.4$ billion over a five year period $^{71}$. There were several other less high profile admissions of corporate malfeasance ${ }^{72}$ and undoubtedly hundreds of others currently hide behind the camouflage of corporate responsibility. Companies like these were already successful by-products of the globalisation process. They had already achieved dominance 
within their respective niches in the market. They were, theoretically, controlled by and accountable to a strict regulatory system. However, corporate greed led to corporate malfeasance and whether such behaviour was caused by the apparent common denominator of business the world over - profit - or whether they were simply suffering from globalisation engendered competitive stress does not matter. What matters is that it raises the question as to the lengths China, a relatively new, under-developed, under-regulated and quasi-capitalist economy might go in order to achieve the illusion of industrial parity referred to above, especially when increased trade in general, and the commitments made as a pre-requisite of WTO membership ${ }^{73}$ in particular, focus financial attention more and more upon the reality of China's economic stature. As a member of WorldCom recently noted, "[t]here were no rewards for saving the company from a potential loss. There were only rewards for doing a deal that could outwardly be reported as revenue or earnings." ${ }^{\text {,4 }}$ There are inevitable moves afoot within the USA to mitigate the perceptual and actual harm done to its financial sector ${ }^{75}$ for as Goldstein (of the Institute for International Economics) has argued "[t]here have been enough serious breakdowns in corporate governance, accounting, auditing and investment banking to make everyone worry.",76 In this regard, the Economist notes, for example, that "[s]ince Enron, Congress and the administration have been talking about reforms to the regulation of auditing and the setting of accounting standards." ${ }^{, 77}$ They might usefully and crucially, however, examine the role, or lack of thereof, of the SEC. As Coffe ${ }^{78}$ has argued, with admirable understatement, "[t]he SEC...has been something of a reluctant regulator."79

In relation to China's regulatory oversight, however, there remains a more pressing problem. As Crockett puts it, "[w]eaknesses in the financial infrastructure can render 
useless the most careful supervisory oversight.. ${ }^{, 80}$ China suffers from poor oversight of a poor financial system and that combination of factors is destined to cause severe problems.

The future of e-trading and globalisation lies in the utilisation and utility of cyber payment systems such as e-cash (whether in smart card or computer-based form). As Fisse and Leonard have argued, "[t]he more automated the banking and financial system becomes, the less face to face contact between clients and employees and the greater the holes in the detection net..." ${ }^{81}$, a process known as disintermediation ${ }^{82}$. Schaechter argues that, in relation to e-banking, "[t]he dependence on technology for providing the services with the necessary security, and the cross-border nature of transactions, involve additional risks for banks and new challenges for banking regulators and supervisors. ${ }^{, 83}$

If the supervision of China's banking system has been so lax as to permit the aforementioned ${ }^{84}$ criminal diversion of funds to occur, one cannot really place too much faith in its ability to adapt to the security challenges posed by cyberpayment systems at all, let alone in time to prevent mass infiltration and abuse of the global market. The BCBS drew up specific e-banking principles in May $2001^{85}$. They concern themselves with risk management for electronic banking, clearly the future of e-commerce and, on the OECD's logic ${ }^{86}$, globalisation. In broad terms, the fourteen principles alluded to necessitate, inter alia, "..effective management oversight" ${ }^{\text {, }}$, the

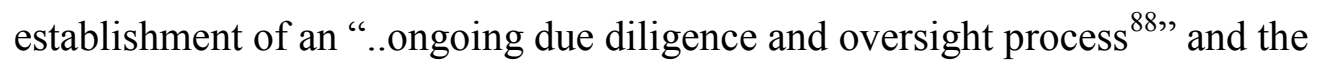
promotion of “...adequate segregation of duties within e-banking systems.." ${ }^{\text {" }}$ and require the relevant banks to ensure that "..clear audit trails exist for all e-banking transactions." ${ }^{, 90}$ It has to be acknowledged that even with the most optimistic of 
outlooks the likelihood of such criteria being met, given China's track record of adherence to the land-based Basel principles, is slim.

The Financial Crimes Enforcement Network (FINCEN) of the US Department of Treasury argues that "inadequately regulated or unregulated electronic banking systems may be used to conduct anonymous transactions and to obscure audit trails, acts that may facilitate money laundering and hinder traditional investigative techniques, especially those requiring the analysis of financial records." 91 The number and variety of crimes that might be committed through the use or abuse of computer systems is already legion ${ }^{92}$. As far as money laundering in particular is concerned, Molander et $a l^{93}$ have maintained that the ease with which cyberpayment systems operate is a double-edged sword. As they put it, "[t]he international dimension of these systems, and the fact that value transfers may take place with rapidity and with a degree of anonymity that impedes oversight by governmental authorities, is clearly a serious concern. ${ }^{94}$ Further, the FATF have noted the dangers inherent in new payment technologies and online banking ${ }^{95}$. Schroeder has argued that "emerging market countries are particularly vulnerable to laundering as they begin to open their financial sectors, sell government-owned assets and establish fledgling markets." ${ }^{.96}$ As has been observed already, the risk to China's financial system, and by definition to the systems of any countries that trade with China, is high. This may be particularly so given the FATF's recent observation ${ }^{97}$ concerning co-ordinated money laundering among organised crime groups, the potential impact of such groups having already been noted ${ }^{98}$.

Given that the International Monetary Fund (IMF) estimates global laundering to account for between two and five percent of global GDP ( $\$ 600$ billion to $\$ 1.5$ 
trillion) ${ }^{99}$ it is a threat China needs to note carefully. China is not, unlike Russia, on the FATF's NCCT ${ }^{100}$ list $^{101}$, but it does appear (as do, inter alia, the UK, Hong Kong and the US) in the International Narcotics Control Strategy Report ${ }^{102}$ as a country of primary concern because of its potential to become a centre for laundering activity. Those institutions which host (wittingly or otherwise) the money laundering activity are increasingly asked to create, enforce and adhere to a wealth of laws, conventions and regulations which operate nationally, regionally and internationally. The fact that such laws appear to treat the professional service providers who perpetrate the laundering as naïve and accidental malfeasants ${ }^{103}$ renders the overall global success of such intervention unlikely. More locally, if the way in which the banking sector in China is regulated is the litmus test for its prospective success in dealing with money laundering then money laundering control within China is likely to be poorly attended to.

More generally, in a test of e-readiness ${ }^{104}$ (the extent to which an economy is conducive to e-business) of the world's sixty largest economies, China was ranked $45^{\text {th }}$. To contextualise this, India (a less developed rather than emerging economy) was placed $49^{\text {th }}$. The computer infrastructure in China is under-developed and, relative to the economies it seeks to business with, unsecure. Indeed, the OECD has noted that "[i]nadequate technology and limited capacity to innovate are particular weaknesses of much of Chinese industry." ${ }^{105}$ The Chinese government has, arguably, added to that security concern by insisting on attempting to control the availability and content of web traffic. Attempting to control the Internet per se and certainly within the context of a globalised economy in which Western companies will be loathe to ignore the potential of the Chinese market, will undoubtedly lead to covert infiltration by those companies. Organised crime groups will exploit this level of 
uncertainty for as Savona notes, "criminal organisations go where opportunities are and the process of globalisation helps the expansion."

Security within companies within Western economies is, relative to potential threat, a low priority ${ }^{107}$. As Butler has argued, "although business was quick to recognise the advantages to be gained from improving connections to the outside world, a corresponding awareness of the unique vulnerabilities of such enhanced connectivity has been far slower to develop." 108 That corporations lack the requisite awareness is evidenced by the number of viral infections and the effectiveness of denial of service attacks the systems have been subject to. Where security is raised, it is invariably raised in the context of treating security as a problem to be solved rather than a holistic process to be observed. The security of China's computer systems is, given the state of its banking and finance sectors and level of corruption, unlikely to be a priority. Indeed, as with most western businesses, if security breaches do occur they are unlikely to be reported. China, as a newly welcomed member of the WTO could not afford the negative impact. In consequence, China could become one of the weak links in the already weak chain of globalisation security.

Although not often mooted, the current global political climate may well render China an amenable target for terrorists and anti-globalisation protesters. Bin Laden saw the widespread economic impact of September $11^{\text {th }}$ upon the capitalist economies of the world. The Economist noted that despite the overall resolve shown by the financial system after the attacks, the attacks nevertheless indicated that "...even where capitalism is well established, it is increasingly vulnerable to those who hate it."109 Given that the eradication of capitalism, or at least the brand of capitalism practised by the USA and its immediate allies, is Bin Laden's raison d'être it seems inevitable that the globalisation process will become his new focus. It seems equally likely 
therefore that fledgling globalising economies will constitute easier and, given increased western investment in them, more devastating targets in the ongoing war against globalisation.

Michael Vatis, a former head of the FBI's National Infrastructure Protection Center [sic] notes "we have seen a clear decision by terrorist groups like Al Qaeda to focus on critical infrastructures, financial networks and power grids." Russia, a globalising emerging economy, is already fearful of movement in this direction. Department R of the Moscow police is Russia's Communication Security Branch. Their key focus in now digital crime. The head of Department R said "[t]his, unfortunately, is the future face of terrorism."

Trott reported in March 2001 that anti-globalisation protesters maintain ${ }^{112}$ that the Internet age is exacerbating the inequality that globalisation per se represents because it both pressures development and increases the digital divide between developed and emerging economies. The OECD has noted ${ }^{113}$ that China's economic growth has actually led to a growing inequality among its regions, with the coastal provinces seeing incomes and living standards rise and the western provinces seeing them fall. Needs which are not met successfully by government are inevitably met by organised crime. Infiltration into the population of China will make criminal infiltration into other sectors all the easier. Chelsea Mozen, an anti-globalisation protester, said after September $11^{\text {th }}$, "I believe the terrorism was awful and horrible, but so is what the IMF does." 114

The US Department of Defence defines terrorism as "the calculated use of violence or the threat of violence to inculcate fear, intended to coerce or to intimidate governments or societies in the pursuit of goals that are generally political, religious or ideological.",115 
Anti-globalisation protesters share, with Bin Laden, an unobtainable goal - the removal of capitalism or at least a minimisation of its perceived exploitative nature. Equating, as Mozen does, September $11^{\text {th }}$ with the policies pursued by the IMF indicates that the transition from violent demonstrations on the streets of Seattle to non-violent disruption of the computer networks which support global economies is not so far away as one might have imagined. China would present the perfect target for terrorists and anti-globalisation protesters especially once the other WTO members have invested their billions of trade dollars and China supplies the world with a substantial volume of its products.

For the globalisation process to take precedence over the safety of the economic, political and financial systems that underpin it, is, particularly in China's case, a travesty. As Confucius had it, "[t]o see what is right and not to do it is want of courage." 116 Unfortunately for China, the fear of not being part of the globalisation process is as much a driving force as the prospect of suffering at its hands.

\footnotetext{
1 'Progress Report on the OECD's Work on Electronic Commerce', January 16-17, 2001, p.3.

${ }^{2}$ ibid, p.6.

${ }^{3}$ Cited by Ridding, J, 'Damned by Progress', Financial Times, FT Weekend, April 27/April 28, 2002 , p.1

${ }^{4}$ Zekos, G, 'Internet or Electronic Technology: A Threat to State Sovereignty', Journal of Information, Law and Technology, No.3, 1999, www.elj.warwick.ac.uk/jilt/99-3/zekos.

${ }^{5}$ The Economist, May 18, 2002, p.12.

${ }^{6}$ ibid.

${ }^{7}$ Dryden, J, 'The Work of the OECD on Electronic Commerce', www1.oecd.lrg/subject/e_commerce/ottawa_speech.pdf.

8 'Conclusions of the Study on Effective Measures to Prevent and Control High-Technology and Computer-Related Crime', Commission on Crime Prevention and Criminal Justice, Tenth Session, May 8-17, 2001.

${ }^{9}$ Noted by Williams, P, 'Transnational Criminal Organizations: Strategic Alliances', The Washington Quarterly, Winter, 1995, www.alternatives.com/crime/crimlink.html.

${ }^{10}$ ibid.

11 ibid.

${ }^{12}$ See Myers, W, 'The Emerging Threat of Transnational Organized Crime from the East', Crime, Law and Social Change, (1995/96, Volume 24, No.3, pp. 181-222.

${ }^{13}$ Cited by Williams, P, 'Organized Crime and Cybercrime: Synergies, Trends and Responses', www.usinfo.state.gov/journals/itgic/0801/ijge/gj07.htm.

${ }^{14}$ The Independent, May 23 2002, p.15.

15 ibid.
} 
${ }^{16}$ Russian Organized Crime, Center [sic] for Strategic and International Studies, 1997, p.26.

${ }^{17}$ See also Finckenhauer, J and Voronin, Y, 'The Threat of Russian Organized Crime', US Department of Justice, June 2001, www.ncjrs.org/pdffiles1/nij/187085.pdf and Foglesong, T and Solomon, P,

'Crime, Criminal Justice, and Criminology in Post-Soviet Ukraine', US Department of Justice, July

2001, www.ncjrs.org/pdffiles1/nij/186166.pdf.

${ }^{18}$ ibid, p.35.

${ }^{19}$ Shelley, L, 'Crime Victimizes Both Society and Democracy', www.usinfo.state.gov/jounals/itgic/0801/ijge/gj06.htm.

${ }^{20}$ Russian Organized Crime, op.cit; p.25.

${ }^{21}$ Finckenauer, J and Waring, E, Russian Mafia in America, p. 150.

${ }^{22}$ Hughes, D, 'The "Natasha Trade": Transnational Sex Trafficking', National Institute of Justice Journal, Number 246, January 2001, www.ojp.usdoj.gov/nij/journals/jr000246.htm.

23 'Time to Trade', The Economist, June 15, 2002, p.93.

${ }^{24}$ ibid.

${ }^{25}$ ibid.

${ }^{26}$ Over the first nine months of 2001, Russian-Chinese trade increased by $31.5 \%$ over the same period in 2000. www.english.pravda.ru/world/2001/10/15/18076.html.

${ }^{27}$ Time, Forecast 2002, February $4^{\text {th }}, 2002$, p. 59 .

${ }^{28}$ ibid.

${ }^{29}$ Roston, E and Fonda, D, 'China's New Party', www.cnn.comALLPOLITICS/time/2002/01/25/china.html.

${ }^{30}$ The Economist Pocket World in Figures, Profile Books Limited (2002), p.124.

${ }^{31}$ ibid.

${ }^{32}$ ibid.

${ }^{33}$ Professor Hu Angang of Tsinghua University, Beijing puts the figure at between 13\% and 16\% and estimates that 15-20 percent of public project funds reach private hands, Asian Wall Street Journal (Singapore) March 19, 2001, cited by Callick, R, 'East Asia and the Pacific', Global Corruption Report 2001, p.11.

${ }^{34}$ Hadekel, P, 'China Meets the WTO', Washington Times, June 22, 2001, cited at www.centerforsecuritypolicy.org/index.jsp?secton=papers\&code $=01-\mathrm{F} \quad 49$

${ }^{35}$ Ridding, J, op.cit.

${ }^{36}$ Cited in 'Something Rotten in the State of China, The Economist, February 14, 2002.

${ }^{37}$ For a broader discussion on the nature and consequences of corruption see Passas, N, 'A Structural Analysis of Corruption: The Role of Criminogenic Asymmetries', Transnational Organized Crime, Volume 4, Number 1, 1998, pp.42-55.

${ }^{38}$ As Myers has it, guanxi is "...a social strategy by which individuals in a hierarchical society seek to insure access to resources, which are controlled by powerful elites, who can arbitrarily allocate them.", Myers, op.cit, p.185.

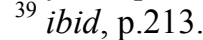

${ }^{40}$ Shuntian, Y, 'Privilege and Corruption: The Problems of China's Socialist Market Economy', The American Journal of Economics and Sociology, January 2002, www.findarticles.com.

${ }^{41}$ Johnston, M, 'Corruption in China: Old Ways, New Realities and a Troubled Future', www.people.colgate.edu/mjohnston/MJ\%papers/\%2001/currhist.doc, p.1.

42 'Something Rotten in the State of China', February 14, 2002,

www.economist.com/displayStory.cfm?Story_ID $=988457$.

43 'China Banking Chief Under Investigation', January 15, 2002,

www.bbc.co.uk/hi/english/business/newsid/1761242.st.

44 'The Bank of China's Black Hole', February 4, 2002,

www.businessweek.com/magazine/content/02_05/b3768065.htm.

45 'Something Rotten in the State of China', op.cit.

46 'Chinese Banks in Debt Crisis', November 1, 2001,www.news.bbc.co.uk/hi/english/business/newsid/1632056.st

${ }^{47}$ Chang, G, 'China's Banks: The Only Two Things You Need to Know', China Brief, Volume 2, Issue 6, March 14, 2002, www.china.jamestown.org/pubs/view/cwe_002_006_001.htm.

${ }^{48}$ ibid.

${ }^{49}$ Cited in 'Money Worries', www.economist.com/displayStory.cfm?Story_ID=1164600.

50 'Fraud Strikes China's Only Private Bank', February 24, 2002, www.bbc.co.uk/hi/english/business/newsid/1839576.st. 
51 'Bank of China's Mounting Problems', February 1, 2002,

www.college3.nytimes.com/guests/articles/2002/0/898075.xm.

52 'Bank of China Reveals \$500m Theft by Officials', March 15, 2002, www.ft.com.

${ }^{53}$ Chairman of the Standing Committee of the National People's Congress, cited in Callick, R, op.cit.

${ }^{54}$ ibid.

${ }^{55}$ Asia Times, July 7, 1999, www.atimes.com/china/AG06Ad01.html.

${ }^{56}$ Cited in 'Bank of China - Reforms Open Pandora's Box', Rating and Investment Information Inc., Asian Focus, April 1, 2002, p.1.

57 'Deepening Reform: The Way Out for China's Banking Sector: Facing the WTO Challenges', March 2002, www.tdctrade.com/econforum/boc/020301.htm.

58 'The Bank of China's Black Hole', Business Week, February 4, 2002, www.businessweek.com/magazine/content/02_05/b3768065.htm.

59 'China in the World Economy: The Domestic Policy Challenges Synthesis Report, OECD, 2002, p.18.

60 ibid, p. 19 .

61 ibid.

${ }^{62}$ 'China Steps Up Stock Market Crackdown', January 10, 2002,

www.news.bbc.co.uk/hi/english/business/newsid/1752758.st.

63 'Securities Market Regulation in the Internet Age', Speech by Dr. Zhou Xiaochuan, Chairman, Chinese Securities Regulatory Commission, www.csrc.gov.cn/CSRCSite.eng/enews/efi20011121.htm.

${ }^{64}$ Chang, G, 'China's Equity Markets: Floating with Helium, Part 1, April 25, 2002,

www.china.jamestown.org/pubs/view/cwe_002_009_003.htm.

${ }^{65}$ China in the World Economy, op.cit, p. $\overline{4} 9$.

${ }^{66}$ ibid, p. 50.

${ }^{67}$ ibid, pp 49-50..

${ }^{68}$ Chang, G, April 25, 2002, op.cit.

69 'China in the World Economy', op.cit; p.61.

${ }^{70}$ Witherell, B, 'Corporate Governance and the Integrity of Financial Markets: Some Current Challenges', www.oecd.org/pdf/M00029000/M00029848.pdf.

${ }^{71}$ The Economist, ‘A Guide to Corporate Scandals', July 10, 2002,

www.economist.com/adenda/displayStory.cfm?story_id=1223312.

${ }^{72}$ Including Tyco, Global Crossing, Vivendi, Merck and Elan. ibid.

73 'WTO Successfully Concludes Negotiations on China's Entry', Press Release, September $17^{\text {th }}, 2001$, www.wto.org/wto/english/news_e/pres01_e/pr243_e.htm.

${ }^{74}$ Financial Times, April 9, 2002, p.30.

${ }^{75}$ See, for example, the passage of s.2673, The Public Company Accounting Reform and Investor Protection Act, www.sec.gov/news/press/2002-104.htm.

${ }^{76}$ Time, July 8, 2002, p. 32.

${ }^{77}$ The Economist, 'Accounting for Change', June 29, 2002, p.14.

${ }^{78}$ Professor of Securities Law, Columbia University, USA.

${ }^{79}$ Cited in Kadlec, D, 'Buy! (I Need the Bonus), Time, May 20, 2002, pp.88-90, at p.90.

${ }^{80}$ Crockett, A, 'Issues in Global Financial Supervision', www.bis.org/speeches/sp010601.htm.

${ }^{81}$ Fisse, B and Leonard, P, 'International Electronic Money Systems and Money Laundering', www.gtlaw.com.au/templates/publications/default.jsp?pubid=158

82 "...the absence of a regulated third party (e.g. a bank) in transfers of financial value between two or more entities.", cited in Molander, R, Mussington, D and Wilson, P, Cyberpayments and Money

Laundering: Problems and Promise, www.rand.org/publications/MR/MR965/MR965.pdf/.

${ }^{83}$ Schaechter, A, 'Issues in Electronic Banking: An Overview', IMF Policy Discussion Paper, PDP/02/6, 2002, www.imf.org/external/pubs/ft/pdp/2002/pdp06.pdf, p.1.

${ }^{84}$ See pp.7-9, supra.

${ }^{85}$ Schaechter, A, op.cit, pp.11-13.

${ }^{86}$ See note 1 , supra.

${ }^{87}$ Schaechter, A, op.cit, p. 12.

${ }^{88}$ ibid.

${ }^{89}$ ibid.

90 ibid.

91 'A Survey of Electronic Cash, Electronic Banking, and Internet Gaming', Financial Crimes

Enforcement Network (FinCEN), US Department of the Treasury, 2000.

${ }^{92}$ Commission on Crime Prevention and Criminal Justice, op.cit. 
${ }^{93}$ Molander, R, Mussington, D and Wilson, P, op.cit.

${ }^{94}$ ibid.

${ }^{95}$ See the Reports on Money Laundering Typologies for 1995-1996, 1997-1998, 1998-1999 and 19992000, www1.oecd.org/fatf/pdf/TY1996_en.pdf; TY1998_en.pdf; TY1999_en.pdf and TY2000_en.pdf.

${ }^{96}$ Schroeder, W.R, 'Money Laundering: A Global Threat and the International Community's Response', FBI Law Enforcement Bulletin, May 2001, p.3.

${ }^{97}$ Report on Money Laundering Typologies, 2001-2002, www1.oecd.org/fatf/pdf/TY2002_en.pdf, Chapter 5.

${ }^{98}$ See pp.3-4, supra.

${ }^{99}$ ibid, p.5

${ }^{100}$ Non-Cooperative Countries and Territories.

${ }^{101}$ Fifteen countries are present on the list as of June 21, 2002. www1.oecd.org/fatf/NCCT_en.htm.

${ }^{102}$ Bureau for International Narcotics and Law Enforcement Affairs, International Narcotics Control Strategy Report, 2001, www.state.gov/g/inl/rls/nrcrpt/2001/c6085.htm.

${ }^{103}$ See McCusker, R, 'Money Laundering Control: Elusive Dream or Achievable Reality?', Journal of Money Laundering Control, Volume Three, Number Three, pp.214-222.

${ }^{104}$ Reported in Perez, B, 'Hong Kong Seen as "E-Ready", Willing and Able', South China Morning Post, May 9, 2001, www.technology.scmp.com.

105 'China in the World Economy', op.cit, p.15.

${ }^{106}$ Savona, E, 'Globalisation of Crime: The Organisational Variable', www.just.unitn.it/trasncrime/papers/Wp15.html.

${ }^{107}$ See McCusker, R, 'E-Commerce, Business and Crime: Inextricably Linked, Diametrically

Opposed', The Company Lawyer, Volume 23, Number 1, January 2002, pp.3-8, and McCusker, R, 'ECommerce Security: The Birth of Technology, the Death of Common Sense?', Journal of Financial Crime, Volume 9, Number 1, 2001, pp. 79-89.

${ }^{108}$ Butler, M, 'Managing Risk', E-Business Review, Vol. 1, No. 7, p.59.

${ }^{109}$ The Economist, 'Capitalism and Its Troubles: A Survey of International Finance', May $18^{\text {th }}, 2002$, p.4.

${ }^{110}$ Cited by Quinn-Judge, P, 'Cracks in the System', Time, June 17, 2002, p.37.

111 ibid.

112 'Anti-globalisation Clashes in Italy', March 17, 2001,

www.news.bbc.co.uk/hi/english/business/newsid_1226000/1226593.stm

${ }^{113}$ OECD, 'China in the World Economy: The Domestic Policy Challenges', p. 27.

${ }^{114}$ Cited in Regnier, $\mathrm{P}$, 'Changing Their Tune',

www.time.com/time/europe/specia/antiglobalization.htm.

${ }^{115}$ Cited at the Terrorism Research Center [sic], www.terrorism.com/terrorism/basics.html.

${ }^{116}$ Confucius, Analects, cited in Quotations, Harper Collins, 1985, p.98. 